\title{
RACE, IDENTITY AND CITIZENSHIP IN BLACK AFRICA: THE CASE OF THE LEBANESE IN GHANA $^{1}$
}

\author{
Emmanuel K. Akyeampong
}

The growth in studies of diaspora, globalization and transnationalism in the past decade has equipped us with unique tools and insights that can be deployed in approaching what are in reality historic phenomena. Frederick Cooper has remarked on how discussions of globalization today lack historical depth in the interconnections they draw, and how in the excitement we overlook globalization's flows and blockages, that it empowers some and disempowers others (Cooper 2001). ${ }^{2}$ Anthony Appiah (2005: 216) comments on the longue durée of globalization, describing the entire history of the human species as the history of globalization. ${ }^{3}$ As I have become conscious of my existence as a transnational citizen of Ghana and the United States, residing in the African diaspora (the United States) but as a member of more recent dispersions, and connected intimately to the country of my birth (Ghana) and the international world of Africanist scholarship through global flows, my mind has turned to issues of polity and citizenship, of territoriality and transnationalism, of race and identity. I have become a student of the African diaspora, and of Africa as a receiving continent of non-African diasporas, particularly the Lebanese in west Africa (Akyeampong 2000).

My interest in the Lebanese in west Africa started in an innocuous way. ${ }^{4}$ In 2000 I was commissioned by the editors of African Affairs to write an article on the African diaspora for the centenary issue of

Emmanuel K. Akyeampong is Loeb Harvard College Professor and Professor of History and of African and African-American Studies at Harvard University. He is the author of Drink, Power and Cultural Change: a social history of alcohol in Ghana, c. 1800 to recent times (Portsmouth: Heinemann, 1996) and Between the Sea and the Lagoon: an eco-social history of the Anlo of southeastern Ghana, c. 1850 to recent times (Oxford: James Currey, 2001).

${ }^{1}$ This article was first presented as the Lugard Lecture of the International African Institute at the AEGIS Conference, University of London, 1 July 2005. I am grateful to Africa's anonymous reviewers for their helpful suggestions on revision.

${ }^{2}$ There are some historicized studies of diaspora and globalization, and an excellent example that uses the Chinese diaspora as a case study is Ong (1999).

${ }^{3}$ Globalization thus refers to the increasing sense of world integration and interconnectedness, facilitated in its most recent phase by jet travel, phones, faxes, satellites and the Internet. This phase has witnessed the fluidity of capital and labour, but largely from the developed to the developing world. Transnationalism refers to the growing ability of international migrants (transmigrants) to develop and maintain multiple relations simultaneously across nation states, and especially between home and host societies. This is in marked contrast with diaspora, which usually originates in the forced dispersion of peoples and results in dwelling in strange lands and a deep longing for home.

${ }^{4}$ I have studied the Lebanese diaspora from the nineteenth century onwards. Lebanon had been part of the Ottoman Empire since 1516, administered with Syria, Jordan and Palestine as greater Syria. In the nineteenth-century diaspora, Lebanese and Syrians were regarded as 
the journal. The article, 'Africans in the diaspora: the diaspora and Africa', had a short section which examined Africa as a receiving area for non-African diasporas, utilizing the Lebanese in west Africa as a case study. In 2001, I was invited by the Centre for the Advanced Study of African Society in Cape Town to expand my insights on the Lebanese in west Africa for one of the workshops that accompanied the conference on race relations in Durban in late August and early September. I accepted the challenge and the result was a paper on African-Lebanese relations in west Africa. ${ }^{5}$ I reworked the Lebanese paper to highlight Ghana as a case study for a public lecture at the Centre for Development and Democracy (CDD) in Accra on 1 November 2001. News of the impending lecture created consternation among the Lebanese community in Accra. Connections that seemed far-fetched to me were drawn, linking the tragedy of 11 September 2001 in the United States to a lecture on the Lebanese in a research centre that ostensibly had received some American funding. The Lebanese community smelt a witch-hunt. In neighbouring Côte d'Ivoire there had been reports in the 1980s of Hizbollah activity that had unsettled established LebaneseIvoirean families (Bigo 1992). Was this an attempt to tar the Lebanese in Ghana with the terrorist brush? At this stage I had interviewed several Lebanese families in Accra, some through the instrumentality of the Lebanese Embassy. I deposited a copy of the CDD paper at the Lebanese Embassy, where several Lebanese families picked up photocopies before the public lecture. Their fears allayed that I was not an agitator, the Lebanese turned up for the lecture in their numbers. Ghanaians were well represented at this forum and officials from the Ghana Police Service, the Immigration Service, the Interior, Foreign Affairs and Industry ministries, and the Ghana Investment Promotion Centre attended in rather formal capacities.

In this lecture I argued for the political integration of Lebanese families, some of which had immigrated to the Gold Coast in the early colonial period. Discussion after the delivery of the paper was animated, as 'Ghanaians' and 'Lebanese' tackled what were considered problem areas in Ghanaian-Lebanese relations. Indeed, I was forgotten, as 'Lebanese' and 'Ghanaians' directed questions at each other. I busily took notes. I had provided a forum for a debate on the political integration of a different racial group into the Ghanaian polity, and why generations after their presence this was still considered problematic. Ghanaian participants in the discussion complained about Lebanese aloofness and the fact that they often married other Lebanese; that those not born in Ghana did not bother to learn a Ghanaian language;

one group and seen as Turkish nationals. The Ottoman Empire's alliance with Germany and Austria in the First World War and the defeat of this alliance placed both Lebanon and Syria under French mandate. Turkish rule in Lebanon and Syria thus ended in 1918. The Treaty of Lausanne in 1924 gave birth to distinct Syrian and Lebanese nationalities, and the Lebanese Republic was born on 23 May 1926. Lebanon became independent in 1943.

5 'African-Lebanese relations in west Africa: a historical perspective' - together with other papers from the workshop - is forthcoming in a volume edited by K. K. Prah. 
that their business practices were shady; and that their tendency to support all political parties was disingenuous. Lebanese-Ghanaians and Lebanese residents complained that after decades of residence they were still treated as political strangers. Gabby Mattouk of Parakuo Estates, a fourth-generation Lebanese-Ghanaian, noted that even with his lifelong Ghanaian friends, whenever it comes to political discussions his attempts to contribute are rebuffed with the statement that 'This is not your country, reserve your comments to yourself.' That even their philanthropic gestures are derided by Ghanaians with comments like: 'Oh, they chopped our money and they are giving it back to us.' Yet Lebanese-Ghanaians are very attached to Ghana and feel ill at ease, with their pidgin Arabic, changed diet and different cultural ways, when they visit relatives in Lebanon. ${ }^{6}$ After the session, several Lebanese acquaintances encouraged me to write on these issues and not to shelve the material I had collected. Maurice Aouad, historian of the Lebanese presence in Ghana, provided me with so many documents, collected over the decades, that I would have found it difficult to walk away from the subject. The Lebanese position is that an initiative by Ghanaian intellectuals will be required to open discussion about the political integration of the Lebanese in Ghana. Those of Lebanese descent could not begin this discussion. This was an astute observation. A bid by returned Ugandan Asians to be listed as one of the country's ethnic groups during the constitutional discussions in the early 1990s had been rejected (Mamdani 2004). The Lebanese-Ghanaian community has cautiously avoided acts that might be seen as overtly political. This does not mean the Lebanese in Ghana are uninterested in politics, for they are keenly aware of how politics shapes the business environment on which their livelihoods depend. Acts of political oppression against the Lebanese community in various phases of Ghana's independent history have taught the Lebanese the value of political quiescence (Akyeampong 2001).

This article examines why it was conceptually difficult to envision a non-black citizen in Ghana - and west Africa - during the period of decolonization, which strikingly was also a period of internationalisms. It interrogates the legacy of colonial legal institutions and the input of pan-Africanism, especially its African-American component, in framing Africa as the place of blacks where race, geography and polity overlapped naturally. It situates this understanding within contemporary notions of

\footnotetext{
${ }^{6}$ The affective ties of Lebanese residents in Ghana, and how Lebanese-Ghanaians reconcile their dual attachments to Ghana and Lebanon, are explored in more detail in Akyeampong (2006). An important distinction is the Lebanese attachment to Ghana as 'place', and not to Ghana as 'polity' or 'political space'. On this the long-term Lebanese resident in Ghana, Maurice Aouad, observed: 'Definitely it is an attachment to a place and not to a government or a political community. They have not actually been involved in politics with a few exceptions, like the half-Lebanese/half-Ghanaian [mixed race] late MP [Member of Parliament] Torbey'. Personal communication, Maurice Aouad, Accra, 26 January 2006. The issue of the Lebanese in Ghana not belonging to a 'political community' is explained further on in the present article.
} 
nationalism and the nation state, which from the nineteenth century had promoted the illusion of 'oneness', an 'ideology of the commonness of origins, purposes and goals that allowed those in power to legitimate rule over large and diverse populations' (Schiller, Basch and Blanc-Szanton 1992: 15). Half a century after the end of colonial rule, social science literature has unpacked the social construction of identity, a veritable Ghanaian 'diaspora' has come into existence, and transnationalism has become a common strategy of survival and prosperity. Why has the political integration of the Lebanese remained a challenge? I seek clues in the nature of Lebanese migration and settlement during the era of colonial capitalism, and how this shaped Lebanese identity and community in ways that have made them distinct. Two key features in the nature of Lebanese immigration continue to work against their political integration. First is the legacy arising from the fact that their presence originated as an 'auxiliary diaspora' tied to British colonialism (Cohen 2003: 84). ${ }^{7}$ Since colonial resentment often could not be directed at the small group of European colonizers, members of the auxiliary diaspora became targets of local hostility. Second, Lebanese families, which constituted economic enterprises, have reproduced themselves in Ghana through a regime of family governmentality that subordinated the interests of sons and daughters to the wider economic interests of the family, a feature that has been described as 'utilitarian familialism' (Ong 1999). ${ }^{8}$ To facilitate production and reproduction of family businesses, Lebanese often married Lebanese, and the practice of endogamy reinforced the perception of this community as separate and aloof.

We often emphasize the labour demands of global capitalism in migration movements and political economy as a framework for understanding diasporas. But within the interstices of global capitalism and worldwide diasporas are families and individuals who forge identities that make sense of the realities of homeland and place of residence, who have economic aspirations and social dreams. And here is where current studies of transnationalism and diaspora, of globalization and cosmopolitanism, can shed light on the historic presence of the Lebanese in Ghana. ${ }^{9}$

\footnotetext{
${ }^{7}$ Cohen points out that: 'Auxiliary diasporas profited from colonial expansion but were composed of ethnically different camp-followers of military conquests or minorities permitted or encouraged by the colonial regimes' (Cohen 2003: 84).

${ }^{8}$ Ong (1999: Chapter 4). Utilitarian familialism seems to be a feature of trading diasporas, of which both the Lebanese and the Chinese are good examples. See also Cohen (2003: 83-104).

${ }^{9}$ Useful works that have aided my conceptualization include Ong (1999); Appiah (2005); Cooper (2001); Schiller et al. (1992); Cohen (2003); Basch, Schiller and Blanc (1994); Castles and Davidson (2000); and Braziel and Mannur (2003). Cosmopolitanism is a product of the processes of diaspora, transnationalism and globalization. It describes the dual citizen or the permanent resident who lives in a country that is not her place of origin. For early proponents of an African identity such as Edward Blyden, nationality and cosmopolitanism were opposed (Falola 2001: 36). In today's multicultural world, Appiah (2005) argues that a
} 
This article is divided into an introduction, a conclusion and four main parts. The introduction has outlined the theoretical framework, and is followed by a section that examines the current Ghanaian appreciation of transnationalism as a resource. The third part of the article provides a brief review of the Lebanese diaspora in colonial west Africa, distinguishing analytically between 'settling' and 'sojourning'. The fourth section interrogates family governmentality and the reproduction of Lebanese family businesses. The fifth section looks at the Lebanese question during decolonization and in independent Ghana, and at the tension between non-African racial identities and citizenship. The conclusion looks beyond indigeneity as the basis of citizenship, and advocates the recognition that cosmopolitans can also be patriots.

\section{A WINDOW ON THE PRESENT: TRANSNATIONALISM AND THE GHANAIAN} POLITICAL ECONOMY

Perhaps no single event drew national attention in Ghana to how many Ghanaians lived outside the country as forcibly as the repatriation of 'illegal' Ghanaians from Nigeria in 1983. Two things stood out about the returnees: the size of the Ghanaian community in Nigeria, and its broad socio-economic base. Official estimates put the returnees from Nigeria at between 900,000 and 1.2 million (Brydon 1985: 570). Considering that the population for the entire country of Ghana was put at about 12.3 million by the 1984 Census, this was almost 10 per cent of the population living outside Ghana in a single African country (Republic of Ghana 1987). The returnees included university lecturers, secondary school teachers, artisans, domestic servants, unskilled labourers and prostitutes. There had been some indication that top civil servants had begun leaving the country from the 1970s, when the economy collapsed. By 1985, according to Emil Rado, Ghana had lost between half and two-thirds of its top professionals to the United Nations and other English-speaking countries (Rado 1986: 563). But the government seemed unaware that ordinary people had joined in what had become a mass exodus.

By the mid-1990s, rough head counts of Ghanaians in major European and North American cities had begun to come in: there were 30,000 Ghanaians in Chicago, 20,000 in Toronto, 15,000 in the Netherlands, and 14,000 in Italy. Remittances from these Ghanaians abroad also caught official Ghanaian attention, while those from the United States alone amounted to between US $\$ 250$ million and US $\$ 350$ million annually. By the mid-1990s, Ghanaian government officials were making trips abroad to convince Ghanaians overseas to invest in the Ghanaian economy. In 1995 the Ghana Statistical Service issued a research publication on international migration, which

cosmopolitan, a 'citizen of the world', can live in and improve the place of her residence even if it is not her place of origin; that cosmopolitans can be patriots. 
paid particular attention to the place of international migrants in human capital formation and capital accumulation (Twum-Baah, Nabila and Ayee 1995). In the year 2001, an amount of US $\$ 517$ million was expected in remittances, which would have made foreign remittances the third major source of foreign exchange after cocoa and gold. It is not surprising, then, that the new Ghanaian government under President J. A. Kuffour organized a 'homecoming summit' in Accra in July 2001 for Ghanaians abroad with the specific agenda of encouraging them to invest their capital and skills in Ghana's economic development. Ghana's ambassador to the United States, Allan Kyerematen, commissioned a 'Skills Bank', soliciting professional Ghanaians in the US to register with the bank and indicate when they could work in Ghana for a few months a year pro bono. In 2003, Ghanaian remittances reached a staggering US $\$ 1.9$ billion, displacing cocoa and gold as the country's leading source of foreign currency. ${ }^{10}$

Foreign direct investment in the Ghanaian economy was still discouragingly low and savvy government officials began to highlight the Asian road to development, pointing to the prominent role of overseas Asians in the growing economies of China and India. The Indian government turned to its nationals abroad after failing to attract major foreign investment when it cautiously opened up its economy in the early 1980s. Indian residents working in high-technology industries in the United States and entrepreneurs in the United Kingdom, particularly, were encouraged to return home, bringing the requisite skills, networks and capital (Lessinger 1992). Chinese from Hong Kong and SouthEast Asia have been lauded for playing a major role in the Chinese economic miracle from the late 1980s (Ong 1999). Many of these Asian investors prefer to keep their families in Western countries, despite their investments in India and China, forging flexible modes of accumulation and residence. Constant comparison in the media of Ghana and Malaysia - both achieving independence in the same year with comparable GDPs, but having sharply contrasting economic stories to tell half a century later - have focused Ghanaian minds on Asia.

Ong has pointed out that transnationalism represents a resource and strategy not only for individuals and families in this globalized world, but for governments as well. Instead of globalization and transnationalism posing a threat to the nation state, the nation state seems to be repositioning and redefining itself to take advantage of transnationalism and the global flows that mark the contemporary international economy. States in developing countries seem to be relinquishing the more technical aspects of development to international agencies, and focusing instead on regulating their nationals, facilitating the movements and activities of the wealthy, and restricting and disciplining the movements and activities of the poor. She refers to the first phenomenon as the 'post-developmental state', and the differential treatment of segments

${ }^{10}$ Fiona Ledger, 'Africa's hidden aid', BBC Focus on Africa (July-September 2004: 36). 
of the population as 'graduated sovereignty' (Ong 1999: 21-2). Thus, in an era of globalization, 'individuals as well as governments develop a flexible notion of citizenship and sovereignty as strategies to accumulate capital and power' (Ong 1999: 6). The Ghanaian government seems appreciative and abreast of these current developments. In 1996 it amended its constitution to allow for dual citizenship, a demand made by Ghanaians resident overseas. The government passed Legislative Instrument (LI) 1690, 'Citizenship Regulations', in 2001 to give effect to the dual citizenship facility. This is something not even India and China have extended to their non-resident nationals.

Considering these crucial developments - the growing Ghanaian understanding of diaspora and remittances, of flexible citizenship and sovereignty, and the keen interest to attract investment (foreign and Ghanaian) - the timing seems auspicious to revisit the Lebanese presence in Ghana and to rethink ways of making them active citizens and key players in the national economy. By the beginning of this twentyfirst century, the 3,000 Lebanese residents in Ghana had established 93 registered companies between 1994 and 2001, according to the records of the Ghana Investment Promotion Centre. These companies ranged from cosmetics and steel industries to broadcasting stations and one of the largest cellular phone networks (Scancom, which cost US $\$ 13.7$ million). These 93 companies had been established at a cost of US $\$ 65,657,000$, of which only one third had been raised through local equity and loans. In terms of the number of investment projects, only the United Kingdom, India, China, the United States and Germany exceeded Lebanon in the list of foreign nationals investing in Ghana. ${ }^{11}$ These do not include the investments of Lebanese-Ghanaians, some of whom came to Ghana in the 1880 s.

\section{'SETTLING' NOT 'SOJOURNING': THE LEBANESE AUXILIARY DIASPORA IN COLONIAL WEST AFRICA}

The Lebanese who came to west Africa were like no other nonAfrican racial migrants: they came in search of a home and nationality. They came to settle, not to sojourn. Whether this was deliberate from the outset or represented a modification of intentions remains unclear. Sojourning involves an oscillation between host society and home, and the first generation of Lebanese who came to west Africa were impoverished and lacked the financial ability to accomplish this. They soon demonstrated an attachment to their host societies, and displayed signs of permanent settlement. It is important that we grasp the domestic factors that underpinned the worldwide dispersion of the Lebanese, especially from the mid-nineteenth century, if we are to understand their willingness to embrace west Africa. Not understanding the context of Lebanese emigration and the complex social processes

\footnotetext{
${ }^{11}$ I am grateful to Mrs Ruth Nyakotey of the Ghana Investment Promotion Centre for sharing this valuable information with me.
} 
and different waves the Lebanese diaspora represented have led to the homogenization of their experience and to their being viewed as a single immigrant community in Ghana. We need to unpack the Lebanese community and make qualitative observations in line with historical reality.

Today the Lebanese/Syrians are found in the United States of America, Canada, Mexico, the Caribbean islands, Brazil, Argentina and other Latin American countries, in Saudi Arabia, Kuwait and the other Gulf countries, in Australia, and in the west African countries of Senegal, Sierra Leone, Liberia, Côte d'Ivoire, Ghana and Nigeria (Hourani 1992). This dispersion gathered momentum from the midnineteenth century in response to rapid population growth in the mountain districts of Lebanon, expansion in the number of missioneducated Lebanese and the search for greener pastures, religious and political persecution (especially the Lebanese civil war of 1860) and the attractive economic and social prospects of North and South America and Australasia for young Lebanese and Syrians (Hourani 1992: 3-11). The emergence of Beirut as a prosperous international port in the nineteenth century facilitated travel (Fawaz 1993). In the nineteenth century, 'Syria' was the name used in the West to denote the geographical region that is now Syria, Lebanon, Jordan and Israel. Lebanon formed part of the Ottoman Empire until 1918, when that empire was dismembered following the defeat of Germany, Austria and Turkey in the First World War.

Maronite Christian immigration into a Druze-dominated Lebanon from the seventeenth and eighteenth centuries resulted in what has been described as a veritable Maronite colonization by the early nineteenth century. ${ }^{12}$ The Maronites were followed by smaller migrations of Greek Orthodox and Greek Catholics migrating from the interior of Syria. The religious character of Lebanon became more complex, encompassing Druze, Maronites, Greek Orthodox and Greek Catholic Christians, a Sunni Muslim majority and a Shi'a minority. To acknowledge the reality on the ground, the Ottoman authorities in the 1840s divided Lebanon into two districts: a Maronite north and a Druze south, a rather porous delineation as there were several Druze in the north and Maronites in the south. This was the set-up for the religious, communal and class wars of the late 1850s with France, Britain, Austria, and Russia backing different religious factions and the Ottomans desperately trying to re-establish their authority. In the wake of the chaos, the Lebanese and Syrians emigrated in large numbers. A silkworm crisis in the midnineteenth century also affected the silk industry, the mainstay of the Lebanese economy. In 1858, an estimated 5,000 emigrants had left from five Maronite villages alone. Between 1900 and 1914, 225,000 Syrians and Lebanese had emigrated and by 1914 emigration was running at

12 The Druze inhabited the mountainous district to the south of Syria, and practised a religion which was an offshoot of Islam, but contained external doctrines like the belief in the transmigration of souls. 
between 15,000 and 20,000 a year (Issawi 1992). The economic growth of the Gulf countries in the 1960s and the Lebanese civil war of 1975 have generated another wave of largely professional Lebanese emigrants (Hourani 1992: 6). The Israeli invasion of Lebanon in 1982 intensified this exodus.

Lebanese emigration to west Africa has been mainly a post-1914 phenomenon with Shi'ite Muslims from south Lebanon predominating. The route of Lebanese emigration was from Beirut to Marseilles, and then the favoured trans-Atlantic crossing to North and South America. The first Lebanese, who landed in west Africa at Dakar in the 1860s, appear to have arrived there in ignorance or through the deceit of ship owners (Leighton 1979: 86). 'Amerka' (America) was an imprecise geographical term that covered the Americas, west Africa and even Australia. It represented economic and social opportunity outside Lebanon. Charles Issawi provides an instructive anecdote: " I am emigrating to that part of Amerka that is under French rule; it is very hot there and the people are black", I was told in the 1940s, about Senegal. On the other hand, "Nayurk" meant the United States...' (Issawi 1992: 30). So, some of the Lebanese who landed in west Africa may have believed they were bound for the Americas, while some who arrived in Marseilles and lacked financial resources for the Atlantic crossing to the Americas may have opted for west Africa. From Dakar, the Lebanese moved southwards along the coast in search of economic opportunity. By the 1890s they were sufficiently well established in Guinea to provide stiff competition to the French traders in the rubber boom of 1900. The French authorities responded by imposing a heavy tax on the Lebanese, which pushed some of them into neighbouring countries like Sierra Leone (van der Laan 1992: 535-6). Prior to this, 1893 has been cited as the earliest date of Lebanese presence in Freetown (Leighton 1979: 86). By the early twentieth century the Lebanese had arrived in the Côte d'Ivoire, the Gold Coast and Nigeria. Lebanese records in Ghana cite William Ibrahim Chebib and Elias el-Khoury as the earliest Lebanese to have arrived in Ghana (then the Gold Coast) in 1884. Though Maronite Christians were prominent in this early emigration, Shi'a Muslims came to dominate emigration to west Africa.

Lebanese emigration and settlement in west Africa was characterized by certain patterns that have influenced Lebanese-African relations and the process of assimilation. Emigration from Lebanon had a localized pattern, and related families moved from a particular locale in Lebanon to settle in specific districts in the west African colonies. In Sierra Leone, Lebanese immigrants came from five main districts in Lebanon: Rahbe and neighbouring villages, El-Metn district, Tleill and neighbouring villages, south Lebanon or Tyre and its hinterland, and Tripoli and a few villages north of there (van der Laan 1975: 234-6). In Côte d'Ivoire one encounters whole clans from south Lebanon, such as the Ezzedines from Dair Qanun an-Nahr, the Fakhrys and Bilals from Zrariyah, and the Nassines from Nabatiyah (Bierwirth 1999: 85-6). This pattern of 
chain migration dated back to rural-urban migration in nineteenthcentury Lebanon, when families and friends from village communities moved to the growing city of Beirut. These village networks provided contacts for jobs and recreated the social space of the village in Beirut (Humphrey 1998: 71-3). Extended to the diaspora, this pattern meant that a sense of community existed even in the early days of Lebanese settlement in west Africa, especially as the extended family became the unit of emigration. Lebanese settlers in west Africa soon sent for their wives and children or had marriages arranged on their behalf, if single, and the wives dispatched to join them. This pattern is instructive, for single men dominate temporary migration, as was the case for colonial officials or African rural-urban migration. Lebanese immigration thus had the markings of permanency, a fact that bothered several educated elites and chiefs in west Africa.

Fleeing an insecure homeland, the Lebanese were in search of a home. Opposed to Ottoman rule and to their designation as 'Turks' by Western powers, they were in search of a suitable nationality. In lieu of a Lebanese or Syrian nationality or citizenship before the 1920s, the Lebanese and Syrians showed a preference for British status in west Africa, and some sought naturalization as British subjects even before 1914 (van der Laan 1975: 238; Issawi 1992: 21). The few Shi'ites who immigrated to west Africa before 1914 were also fleeing possible conscription into the Turkish army. Commenting on early Lebanese immigrants to Sierra Leone, van der Laan opined that: 'All the families that came to Sierra Leone before 1914 had considered a complete break with their home country, and aimed at building up a new life abroad, an attitude which also influenced their children' (van der Laan 1975: 238). Lebanese emigrants retained ties with their homeland, for they had left relations behind. Even before the First World War, remittances from the diaspora to Lebanon had reached an estimated $£ 200,000$ sterling by 1900 and $£ 800,000$ by 1910 (Issawi 1992: 26). Instructively, these early remittances aimed largely at maintaining family units at home rather than at a wholesale repatriation of wealth. As Albert Hourani observed, such remittances

have enabled families to buy land and bring it into production, to rebuild the family home in the village with stone walls and red tiles on the roof, and to educate the younger children and so fit them to move in their turn down from the mountain to Beirut or into the outside world. (Hourani 1992: 11)

Lebanese in the diaspora always yearned to visit home, but the persistence of the conditions that had spawned their emigration in the first place made these visits home temporary. Robin Cohen has commented on an 'almost palpable physical nostalgia' for home which sustains Lebanese culture in the diaspora and draws Lebanese from far-flung outposts to visit Lebanon (Cohen 2003: 98-9).

It is striking how few Lebanese in the diaspora applied for Lebanese or Syrian nationalities, when these became available under French mandate between August 1924 and August 1926. From the end of the 
First World War up to 1924, the Syrians/Lebanese lacked a nationality following the abrogation of Turkish nationality and before the advent of distinct Lebanese and Syrian nationalities. They came under French protection overseas, the French being eager to benefit from the commercial links of the Lebanese diaspora and the Lebanese role as ambassadors of the French language overseas. The Treaty of Lausanne, ratified on 6 August 1924, gave birth to the Lebanese and Syrian nationalities. Lebanese and Syrians in the newly demarcated republics of Lebanon and Syria automatically assumed these nationalities, and Lebanese and Syrians abroad were given up to 6 August 1926 to apply for their nationalities through the French consulates in their respective foreign countries of residence. Of an estimated 500,000 Lebanese in the diaspora, only 23,463 had applied for Lebanese nationality by this deadline. Many Lebanese had acquired foreign nationality, while many who had not still chose not to assume formal Lebanese or Syrian nationality. There were 1,932 applicants from all of French Africa, which had an estimated Lebanese population of 5,796. None of the estimated 70 Lebanese in Liberia applied for Lebanese nationality. In all of west Africa there were 132 applications. Only 22 applied for Lebanese nationality through the Sierra Leone consulate, and three from Accra in the Gold Coast (Hashimoto 1992). In 1924 the estimated population of Lebanese in Sierra Leone was 729 (van der Laan 1975: 7). The 1931 Gold Coast Census (Gold Coast 1932: 23) counted Syrians and Lebanese as a single group and provided a total of 570 Syrians. And the 1931 Nigeria Census enumerated 419 Syrians and Lebanese (Bauer 1954: 157). That only 132 Syrians and Lebanese in west Africa applied for nationality by the 1926 deadline might underscore commitment to their new homes and/or the complications of dual nationality.

\section{FAMILY GOVERNMENTALITY: (RE)PRODUCTION IN LEBANESE FAMILY BUSINESSES}

Between 1910 and 1945, the Lebanese came to play an important middleman role in west African commerce, occupying the strategic space between large European importers and exporters and west African consumers and agricultural producers. This was not by British design, as British colonial governments in west Africa were not actually supportive of Lebanese immigration. Beirut, at the centre of what has been described as the 'Merchant Republic of Lebanon' (Gates 1998), socialized even rural migrants to aspire to trade and commerce. For the nineteenth century, Leila Fawaz noted that:

Even people of simple background through assiduity, ingenuity, and education could become self-made men by amassing capital as money changers and lenders, interpreters, small-scale venture capitalists, agents of foreign commercial houses, and middlemen in domestic trade. (Fawaz 1983: 123)

In the worldwide diaspora, the first generation of Lebanese immigrants aspired to be self-employed, often choosing to be itinerant 
peddlers of a few trading commodities rather than someone's employee. This aspiration would converge with the interests of British mercantile capital to extend markets and expand the production of primary products.

As Lebanese peddlers and traders moved away from the colonial capitals in west Africa into the hinterland - along railways and then later along lorry roads - they facilitated the incorporation of the African hinterland into the European cash economy. They bulked up agricultural produce for transport to European exporters at the ports, and they broke down imported consumables into small units affordable to Africans. Lebanese traders created new consumer tastes by diversifying the goods on sale in the interior. In Nigeria itinerant Lebanese peddlers even supplemented their meagre earnings through street singing and musical performances (Falola 1990: 529). This was a yeoman's task that European employees turned down because of the associated hardships and unattractive wages, and which European firms were unwilling to entrust to Africans whom they distrusted. In the age of scientific racism, whiteness certainly had its advantages and race may have paved the way for the commercial role of the Lebanese. This is not to diminish the achievements of Lebanese traders, who literally pulled themselves up by their bootstraps. Aspiring to become a 'trading diaspora', they also became an 'auxiliary diaspora', beneficiaries of British imperialism and colonial capitalism, and targets of indigenous west African hostility.

Through frugality, overhead costs kept low by using the family as the unit of trade, enormous personal sacrifice and shrewd business practices, the Lebanese in west Africa emerged as a significant entrepreneurial class. Family and kinship played an important role in this development. In Ong's study of the Chinese diaspora, she develops the concept of utilitarian familialism: how in Chinese trading families, the interests of sons and daughters were always subordinated to that of the father and the overall economic well-being of the family. Sons were expected to assume their assigned roles in the family business. Daughters had no place in the running of the family business, but in families without sons the strategic marriages of daughters brought in sons-in-law, even foreigners, who could become instrumental in the running of the family business (Ong 1999: 125-6). That this strategy would also be manifested among Lebanese business families should not be surprising as the Chinese and the Lebanese are prime examples of trading diasporas. But, here again, the Lebanese were also drawing from local resources and strategies that developed in nineteenth-century Beirut, for features such as parallel and cross-cousin marriages that facilitated family immigration show up even among the Lebanese in Sydney (Australia), where they constitute more of a proletarianized community than a trading one. Lebanese fathers and brothers arrange marriages for their daughters and sisters, with a preference for close-kin marriages as these are considered more secure and the bridewealth involved is much lower than for an out-marriage (Humphrey 1998). 
In considering the role of the family as an economic enterprise, Michael Humphrey observed of the Lebanese in Lebanon that:

The family was the focus of economic activity - if not an economic unit - across all classes in the society. Manufacturing, retail stores and commercial enterprises were predominantly family firms. Also partnerships and corporations were generally partnerships of siblings, cousins or other extended kin and very often corporations were nothing more than legal protection for wholly family-owned or extended kin-owned establishments. Recruitment of migrants into wage labour also relied upon kin connections. Family dependence rather than class-based collective bargaining was the primary mode of economic security. (Humphrey 1998: 73)

In colonial Gold Coast, the family constituted the bedrock of Lebanese/Syrian businesses. From the detailed biographical profiles submitted by Lebanese/Syrians in the Gold Coast applying for naturalized status as British subjects in the colonial era, it would seem that few were married to Ghanaian women. Lebanese men often came to colonial Gold Coast alone; in some cases a wife followed in a year or two, in others single men returned to Lebanon to marry. Three specific family histories will illuminate how Lebanese families and family businesses were reproduced over the generations, though the examples can be multiplied. The first comes from immigration records, the second and third from the private papers of Maurice Auoad.

John B. Moukarzel in his naturalization application of 1935 noted that his father, B. K. Moukarzel, came to the Gold Coast in 1908, and Mrs Moukarzel followed the next year. John, born in Balchibab, Lebanon, was brought to Ghana in 1920 as a minor to join his merchant father in Kumasi. John returned to Lebanon to marry Josephine Thome on 26 April 1936. His wife Josephine returned to Lebanon to give birth to their children, Eugenia and Farouk, and at the time of application both children resided at Cornet el Hamra in Lebanon. Significantly, neither Moukarzel senior nor his wife had visited Lebanon since their arrival in the Gold Coast in 1908-9, but the reproduction of the family and the family business necessitated that they remain connected to Lebanon, sending their children home for what seemed like arranged marriages. ${ }^{13}$

The two other examples illustrate how this family governmentality plays out over two and three generations among Lebanese business families in Ghana, and how the family functions as a unit of production and reproduction. The Halabi family is an important LebaneseGhanaian business family in Ghana, and the founder of the business, Anis Halabi, came to Ghana as a single man in 1943. He set up his first business in Wa in the then Northern Territories of the Gold Coast selling materials and ammunition for hunting guns. He expanded to Tamale, and his brother Rafick managed a similar business in Kumasi. Anis later came to own petrol stations and branched into transport and

${ }^{13}$ Public Records and Archives Administration Department (PRAAD), Accra, CSO 26/4/124. Several similar examples can be cited from the naturalization biographical profiles. 
automobile spare parts. After eleven years in the north, he relocated to Kumasi. With the business well established, Anis went back to Lebanon and got married to Iffat Aqwar. In the 1970s, Anis moved into manufacturing, a move required of Lebanese businesses by the Ghana Business Promotion Act promulgated by the Busia government (1969-72). This Act restricted businesses with an annual turnover of 500,000 cedis (the Ghanaian currency) or less to Ghanaians. ${ }^{14}$ In the 1970s Anis established a leather factory, and he started a galvanized sheets factory in the early 1980 s to produce roofing sheets for the local market. To ensure the reproduction of the family business, especially in its new technological direction, Anis sent his son Adonis (born in Kumasi in 1962) to university in Beirut and then to the University of Michigan, where he trained in mechanical engineering. Adonis gained valuable experience working with Kodak in the United States before returning to take his place in the family business in Ghana. The galvanized sheets factory is wholly owned by Anis and his two sons. Following the family pattern, Adonis returned to Lebanon to marry Diana Abdolbaki. ${ }^{15}$

The Laba family owns several business concerns in Ghana such as Latex Foam, Acapulco, Pipes and Plastics, and Moon Beam. The patriarch of the family, A. S. Laba, arrived in the Gold Coast at the end of the nineteenth century and settled in the town of Cape Coast. As a merchant he dealt in general goods and established branches in other towns. He later moved to Accra, where Suleiman Laba was born in 1902. Suleiman would marry Emily Rizk, a Lebanese woman, and the marriage would produce six children. The two older sons, Eid (born in 1941) and Nawfal (born in 1946) would come to head the family business after Suleiman's death in 1966. Both Eid and Nawfal acquired their education in Ghana and Lebanon, becoming versed in both cultures. In 1965 Eid married Haifa Adi, a Lebanese woman born in Ghana, and the marriage produced three sons - Charles (born 1966), Ghassan (born 1969) and Wissam (born 1974). Nawfal Laba, the other

\footnotetext{
${ }^{14}$ In the early 1970 s, 2.70 cedis was the equivalent of US $\$ 1$. Foreign investment in Ghana is currently regulated by the 'Ghana Investment Promotion Centre Act, 1994 (Act 478)'. Section 19 of that Act sets investment thresholds for enterprises involving foreigners. In the case of a joint enterprise with a Ghanaian partner, the non-Ghanaian must invest foreign capital of not less that US $\$ 10,000$ or its equivalent worth in capital goods by way of equity. Where an enterprise is wholly owned by a non-Ghanaian there is a required investment of foreign capital of not less that US\$50,000 or its equivalent in capital goods. In the case of a trading enterprise which is partly or wholly owned by a non-Ghanaian, the required level of foreign capital investment goes up to at least US $\$ 300,000$ or its equivalent in capital goods. Thus the higher threshold for non-Ghanaian involvement in commerce continues.

${ }^{15}$ I am grateful to Maurice Aouad for sharing his numerous interviews with Lebanese families in Ghana with me. It is instructive that Auoad is one of the few Lebanese who married a Ghanaian woman. Aouad had come to join his Uncle, Elias Joseph Aouad, a merchant, who had settled in the Gold Coast in the 1940s. All the four Aouad brothers - Maurice, Antoine, Joseph and Milad - eventually immigrated to Ghana. Aouad went into broadcasting and education, and perhaps this relieved him of the need to marry a Lebanese. His brother Joseph, who joined his uncle in business, did marry a Lebanese. Interview with Maurice Aouad, Accra, 31 July, 3 August, and 7 August 2004.
} 
brother of Eid, in 1972 married Fatat Farhat, a Lebanese woman born in Ghana. Their marriage produced a daughter Samayah (1973) and a son Richard (1977). Eid and Nawfal established Latex Foam, manufacturer of foam mattresses, in 1969. The education of the third generation of Labas combined schools in Ghana and Lebanon. Instructively, and reflecting the shift into manufacturing for the family business, the three sons of Eid all acquired engineering degrees, Charles and Ghassan from George Washington University and Boston University respectively. The three engineers have expanded the family's business concerns by establishing Pipes and Plastics (a manufacturer of PVC pipes) in 1995, and Moon Beam, a digital communication and information technology company which was the first to manufacture and distribute satellite dishes in Ghana. The brothers have also set up an assembly plant for computers.

As a trading and auxiliary diaspora, with their exclusively familyowned businesses, historically the Lebanese have attracted the hostility of west Africans. An early manifestation of African resentment of Lebanese economic achievements came in the 1919 anti-Syrian riots in Sierra Leone. The Creoles specifically blamed the Lebanese and Syrians for the high cost of rice, the Sierra Leonean staple. But underneath was a deeper Creole resentment of the increasing Lebanese middleman role in commerce to the detriment of the Creoles. By 1919 the Lebanese had captured the trade in kola and rice, which had been in the hands of Creole traders. In the 1919 riots, the Lebanese and Syrians were put under protective custody for their own safety (van der Laan 1975: 3). Elite African resentment of Syrian-Lebanese presence in west Africa was reflected in a resolution at the March 1920 meeting of the National Congress of British West Africa that Syrians in the west African colonies be repatriated as 'undesirables and a menace to the good government of the land' (Boahen 2000: 128). The Congress, formed by the educated African elite in the four British west African colonies, was the first supra-colonial political organization in west Africa. Resentment of Lebanese presence in the region would mount during the economic depression of the 1930s, following the historic pattern of blaming alien commercial classes for economic downturns. As west Africa moved towards decolonization in the 1940s and 1950s, Africans would galvanize to rid themselves of these colonial auxiliaries, as their separateness and relative wealth was a telling reminder of colonial privilege and a colonial system Africans sought to dismantle.

DECOLONIZATION, INDEPENDENCE AND THE LEBANESE QUESTION: RACE, IDENTITY AND CITIZENSHIP

The devastating impact of the Second World War on Britain was phenomenal and its economy was shattered. France had been defeated and occupied by Germany as early as 1940 . The crystallization of Asian nationalism and the independence of India, Ceylon and Burma in the late 1940s prepared Britain for a similar eventuality in its west African 
colonies. As Britain and France moved to harness the economies of their African colonies to metropolitan reconstruction, Britain decided to jettison Indirect Rule based on chiefs for a partnership with the educated African elite. Britain knew that political concessions would have to be made if this new partnership was to succeed. These concessions set the west African colonies on the road to decolonization. The process involved the privileging of an African political and economic agenda and, as decolonization picked up pace, a power transfer with a decidedly African imprint. How did the Lebanese and Syrians fit into the British plans for decolonization?

From the 1930s immigration policies relating to the Lebanese and the Syrians were tightened in Nigeria and the Gold Coast. With the move to decolonization, Britain sought to avoid the complications that may arise from the presence of substantial non-African populations. Britain also committed itself to promoting the economic and social development of the African population. An official Gold Coast statement in February 1949 sums up this position:

It has long been the policy of the Gold Coast Government to prevent nonAfrican settlement in the Gold Coast. The purpose of this is to ensure that the indigenous population should be allowed to progress without the eventual complications of pressure from powerful and strongly entrenched nonAfrican interests, not only in the political sphere but also in the commercial and economic spheres. ${ }^{16}$

Bauer highlights the British official belief that the amount of trade in west Africa was fixed, and that economic participation involved a zero-sum game. To privilege the African economic agenda entailed scaling down Lebanese and Syrian involvement in those sectors of the economy earmarked for Africans (Bauer 1954: 159). African politicians accepted this interpretation and relations between African and Lebanese businessmen were cast in adversarial terms. Colonial policy from the 1940s firmly directed non-African investments into manufacturing and not trade, as trade - especially retail and semi-wholesale trade - was designated an African sphere. Non-African businesses could thus pioneer investments that required far more capital than the African possessed.

Significantly, decolonization in British west Africa rejected the multiracial society that colonialism had spawned inadvertently. The colonial report for Sierra Leone in 1952 bluntly stated that: 'No provision exists for permanent settlement by non-natives in the Protectorate' (van der Laan 1975: 273). What would be the political status in west Africa of the Lebanese, some of whom were of the second and even the third generation? Would they be considered temporary immigrants or settlers? In the case of Sierra Leone, van der Laan points out that all the Europeans and the Indians were temporary immigrants.

16 Gold Coast, Gazette Extraordinary, February 1949, as cited in Bauer (1954: 158). A similar position was enunciated in the Nigerian immigration policy of 1952 . 
Attention focused on the Lebanese, who certainly differed from the Europeans and Indians, but who still maintained ties with the homeland and thus could not be seen as 'true settlers' (van der Laan 1975: 273). They had erected cement houses, a sign of permanent settlement, and were raising children and grandchildren born in Sierra Leone. A misunderstanding of the nature of diaspora created the misimpression that one could not have two homelands. This sentiment would feed into the post-independence discussions of (dual) citizenship.

There were two categories of Lebanese in colonial British west Africa: the aliens and those with British-subject status. All second-generation Lebanese were British protected persons or, from 1949, 'Citizens of the United Kingdom and the Colonies'. But this was an imperial and not a national identity. Decolonization was a prelude to the formation of nation states. And 'most British officials believed that the Lebanese with British status could be absorbed neither in the African nor in British society' (van der Laan 1975: 274). The anomaly lies in the fact that the concept of citizenship promoted by British colonial rule was exclusive and not inclusive, uniracial and not multiracial. It drew its inspiration from early-nineteenth-century ideas of nationhood that assumed a naturalness about the new nation states that replaced the old European monarchies, and subsequent ones that were established around the world. An important outcome of this process of creating nation states was an essentializing of nations, presenting national populations as bound by history, culture, language, faith and even biology. Traditions were invented to bolster the credentials of these new nations. When this spirit of invention was deployed towards colonial Africa, since Europeans also believed that Africans belonged naturally to 'tribes', the colonial powers fastidiously delineated the boundaries of each tribe within what came to be called 'native states' (Ranger 1983: 212). The creation of tribes was entwined with the reification of race in the construction of the new European nation states: races were civilized, created nations and governed by law; tribes were uncivilized and were governed by custom (Mamdani 1996). A tribe was defined as a group with a shared origin, language, culture and territory; an inferior copy of the civilized European nation state. This opposition of nation and tribe transformed African nationalism into a struggle by Africans to be recognized as a race, as 'Africans', and as a race to gain access to the world of rights, to the community of civilized societies (Mamdani 2004).

Though the post-Second World War era witnessed several forms of internationalism from which African nationalists could have drawn, including some advocating a world government with world citizens or a world without states, those that had political support - like the United Nations (UN) idea - envisaged a world with nation states all treated as equals. The ascendancy of the UN sanctified nation states as actors. The call for other types of internationalism, such as the 'One World' advocated by Albert Einstein and his fellow nuclear scientists between 1945 and 1955, did not thrive. For Einstein and his colleagues, it was the existence of sovereign states possessing great power that had 
plunged the world into war, and the continuance of these states made war inevitable. ${ }^{17}$

Pan-Africanism, another form of internationalism that peaked after the Second World War, was also hamstrung by the prevailing ideas of race and nationhood. Indeed, generations of racial discrimination against African Americans in the Americas had convinced many of them that dignity, freedom, unity and material prosperity would only come if those of African descent returned to Africa. From the time of Edward Wilmot Blyden (1832-1912) Africa has been presented as the place for Africans and the site for the fulfilment of African potential (Falola 2001: 36). The elevation of race in the United States and the insistence that biology and not culture should be the prime determinant of differentiation underscored for African Americans the overlap between race and territory (Schiller, Basch and Blanc-Szanton 1992: 17). Basch, Schiller and Blanc observe that the notion of 'whiteness' has been at the core of the construction of the nation in the United States, and this has disprivileged Native Americans and African Americans (Basch, Schiller and Blanc 1994: 40). This reality influenced pan-Africanism, making it - in turn - difficult for educated Africans in the 1940s and the 1950 s to conceptualize a post-colonial polity that was not framed by race. Indeed, to talk about the nation is to talk about race, as the 'nation stands in opposition to those defined as biologically different only by envisioning the nation as composed of those who are biologically similar' (Basch, Schiller and Blanc 1994: 37). Achille Mbembe points out that:

Pan-Africanism in particular defined the native and the citizen by identifying them with black people. In this mythology, blacks do not become citizens because they are human beings endowed with political rights, but because of two particularistic factors: their colour and privileged autochthony. Racial and territorial authenticity are conflated, and Africa becomes the land of black people. Since the racial interpretation is at the foundation of a restricted civic relatedness, everything that is not black is out of place, and thus cannot claim any sort of Africanity. (Mbembe 2002: 256)

This fusion of the 'spatial body, the racial body, and the civic body' had become so entrenched in African thought that it would shape the resolution of the Lebanese question on independence.

How were the Lebanese and the Syrians incorporated in the post-colonial political dispensation? On independence, all the west African nation states rejected dual citizenship. This, together with the Africanization of business, compelled several Lebanese to naturalize. The passing of the Ghana Nationality Act in 1957 encouraged many second- and third-generation Lebanese to assume Ghanaian citizenship through naturalization to protect their businesses. Sierra Leone asked

17 Einstein spent the last ten years of his life (1945-55) campaigning for his ideal of world government. He wrote works such as Why War, and his writings on peace were compiled posthumously. See Malkki (2005). 
the Lebanese holding Sierra Leone passports to surrender their Lebanese and British passports. The 1960 Independence Constitution of Nigeria made a provision for the naturalization of Lebanese, especially those born in the country before 1962 (Falola 1990: 551). In the 1960s, several Lebanese in Senegal, notably those in the transport sector, acquired citizenship. In the late 1960 s and 1970s, the Senegalese government pressurized Lebanese applicants for naturalization to give up their Lebanese citizenship as a condition of naturalization (Boumedouha 1990). In the Côte d'Ivoire by 2000, about 10 per cent of the Lebanese had acquired citizenship, but even these were still considered 'strangers' and excluded from national politics. Bierwirth's observation that 'there is an implicit "colour bar" to political participation in Côte d'Ivoire' holds true for Ghana (Bierwirth 1999: 92-3). Politics is reserved for Africans.

Here, it is important to unpack the apparent contradiction between the economic wealth of the Lebanese in Ghana and their lack of political power. Individual Lebanese-Ghanaians and Lebanese residents may be influential, but this influence is exerted behind the scenes through their connections to top government officials. The Lebanese in Ghana-Lebanese-Ghanaians and Lebanese residents - do not constitute a 'political community'. By this I mean a group of people who share similar beliefs, values and positions; who are conscious of their political rights; and who can organize in pursuit of these political rights. There is a Lebanese Association in Ghana, and it is active through social clubs (Lebanon Club), philanthropic activities and representations to government on business issues. But the Lebanese are distinctly apolitical. The Lebanese experience with Ghanaian politics in the independence era sheds light on this position. Two examples will suffice. The first is an episode from 1969, the second from 1979.

In late September 1969, two weeks after Dr K. A. Busia's Progress Party came into power, the government withdrew the residence permit of Omar Captan, managing director of the Captan group of companies. ${ }^{18}$ Four Captan brothers had immigrated to Ghana in the 1930s. They were prominent in the cinema business and had established a string of cinema halls including the Odeon in Kumasi and the Opera, Orion, Plaza and Dunia, all in Accra. Though Omar Captan had been eligible for Ghanaian citizenship through naturalization on independence, he chose not to apply. The favourable stance of Kwame Nkrumah, Ghana's first prime minister, towards foreign investors in the early years of the government protected Lebanese gains in the Ghanaian economy. A very old friendship with K. A. Gbedemah, finance minister in the Nkrumah government, was certainly a factor in Captan's sense of security. The overthrow of Nkrumah in a military coup in February 1966 witnessed assaults on Lebanese properties. The Mattouks, lengthy residents in Ghana, had their house attacked. Devastated by this incident and their sense of security shattered, the

${ }^{18}$ Daily Graphic, 15 October 1969. 
parents relocated to Lebanon. Piccadilly Factory, belonging to the Eid family, was also vandalized, though he was a Ghanaian citizen. In the aftermath, Eid relocated his family to Lebanon. ${ }^{19}$

In June 1969, Omar Captan, obviously disturbed by what appeared to be racial hostility towards Lebanese residents and Lebanese-Ghanaians, filed for Ghanaian citizenship. But an incident in the run-up to the elections of August 1969 would mar his future in Ghana. In the prelude to the elections, Captan had allowed Gbedemah and his National Alliance of Liberals (NAL) to hold a meeting at his Accra residence. Captan believed that to absent himself physically from the meeting would disconnect him from Gbedemah's politics. ${ }^{20} \mathrm{He}$ was obviously mistaken, and the Progress Party government regarded him as a financial backer of NAL. Although the outgoing National Liberation Council had apparently approved Captan's naturalization application and he had paid the fee for the naturalization certificate on 12 September 1969, the new government rejected his application, withdrew his residence permit, and ordered him to leave the country. After a futile legal battle, on 5 February 1970 the 60-year-old Captan left Ghana after 35 years of residence. He then lived in Lagos, to be near Ghana, but died the following year. In November 1969, the Busia government passed an Aliens Compliance Order, expelling illegal aliens from Ghana. Two thirds of the 12,000 Lebanese in Ghana left for neighbouring countries, the Gulf States and Saudi Arabia. The Lebanese community in Ghana never regained its numerical strength. As a form of insurance, Lebanese businesses tend to make multiple investments, often in neighbouring west African countries, thus securing the option of multiple places of residence. Though elderly Lebanese residents retire to Lebanon, as distinct from Ghanaian-Lebanese who are sometimes buried in Ghana, Lebanese businessmen often choose to try their luck in neighbouring west African countries when their businesses decline or collapse, rather than returning to Lebanon. ${ }^{21}$

The second episode which nudged the remaining Lebanese in Ghana toward political quiescence was the hostile attitude of the Armed Forces Revolutionary Council (AFRC) in its four-month regime (4 June-24 September) in 1979. Led by Flight-Lieutenant J. J. Rawlings, the regime's antagonistic position towards the Lebanese and Indian communities in Ghana was presaged in the statements of Rawlings

\footnotetext{
${ }^{19}$ Personal communication from Tony Eid, Chargé d'Affaires, Embassy of Lebanon, Accra, 6 February 2006.

${ }^{20}$ Daily Graphic, 20 November 1969.

${ }^{21}$ The interconnectedness of Lebanese networks in west Africa partly explains this phenomenon. Lebanese investors in west Africa were either born there, lived there at some point in time, or have relatives in the region. The difficulty of setting up in business in Africa makes it rare for a Lebanese with no links to west Africa to set up business there. Lebanese investors in Ghana thus insert themselves into pre-existing networks, and seldom approach the Lebanese Embassy in Accra to facilitate their business. Interview with Tony Eid, Chargé d'Affaires, Lebanese Embassy, Accra, 6 February 2006. A collapsed business endeavour often leads to a move to a neighbouring country with an established Lebanese presence.
} 
during his court martial for his abortive coup attempt in May 1979. The Director of Public Prosecutions, G. E. K. Aikins, managed to transform a law-breaker into a national hero, as he recounted the reasons Rawlings gave for his attempted coup. The public in the gallery at this open trial applauded loudly when the prosecutor touched on Rawlings's reported dismay that while ordinary Ghanaians could not afford decent meals the Syrians and Lebanese had amassed enormous wealth through their 'nefarious activities'. Part of the planned unsuccessful coup involved the bombing of industrial buildings owned by the Lebanese and Syrians. ${ }^{22}$

A successful military coup on 4 June 1979 liberated Rawlings and his accomplices, and a new AFRC regime was installed. Its short tenure before its hand-over on 24 September to a civilian government elected on 18 June was an unpleasant period for Lebanese, Syrians and Indians. Tensions peaked when in the week after the 4 June coup the government publicized an alleged bounty the Lebanese and Indian communities had placed on Rawlings's head. In published statements, both the Lebanese and Indian communities denied the allegation and affirmed their support for the AFRC. A press release from the Lebanese Embassy stated that the embassy was 'fully against any interference in the internal affairs of Ghana, and the Lebanese therefore do not interfere in the politics of this country'. ${ }^{23}$ Though no arrests followed, an immigration crackdown led to the deportation of 36 illegal aliens, including 23 Lebanese and 10 Indians. ${ }^{24}$

On 4 August all 'non-African immigrants' in Ghana were asked to report to the immigration authorities in the various regions with their passports for registration. All re-entry visas issued between 4 June and 30 June to immigrants who intended to travel outside the country and return were cancelled. ${ }^{25}$ Major Lebanese businesses such as the Aschkar and the Fattal groups of companies were nationalized. In 1978 the previous government had commenced the nationalization of components of the Fattal group of companies, accusing the group of 'using a cloak of naturalization to cover up frauds and disruptive trade practices' ${ }^{26}$ By mid-August 1979 the AFRC government had started an inquiry into the citizenship status of several naturalized Lebanese and Indians. It pledged to revoke Ghanaian citizenships it deemed illegally acquired. The AFRC liaison officer at the Ministry of Internal Affairs pointed out that, of the 119 persons who were granted citizenship between 1972 and 1974, 80 per cent were Lebanese and Indians. Of the 150 persons who naturalized between 1975 and 1978, 90 per cent were Lebanese. ${ }^{27}$ The AFRC subsequently passed the Ghana Nationality (Amendment) Decree, 1979 (AFRCD 42) on 4 September

\footnotetext{
22 Ghanaian Times, 29 May 1979.

23 Ghanaian Times, 11 June 1979.

24 Daily Graphic, 1 July 1979.

25 Ghanaian Times, 4 August 1979.

26 Ghanaian Times, 29 August 1979 and 5 September 1979.

27 Ghanaian Times, 16 August, 1979.
} 
1979, denationalizing dozens of Lebanese. Though many were allowed to stay in the country and use their Ghanaian passports on a temporary basis following legal petitions, the decree remains on Ghana's statute books and the status of those affected in 1979 remains unresolved. It appears that the process of naturalization has become particularly tedious in the last two decades, and since 1993 no non-Ghanaian has been granted Ghanaian citizenship by naturalization. ${ }^{28}$

Though the conventions of a trading diaspora have schooled the Lebanese to focus on business, be philanthropic, and stay out of politics, this has become increasingly difficult for second-, third-, and fourthgeneration Lebanese-Ghanaians to accept. In the Ghanaian elections of 2004, the Lebanese-Ghanaian Gabby Mattouk was encouraged by the Lebanese community to run for a parliamentary seat. There was an intriguing divide among those who advocated this. For some, Mattouk's bid for a parliamentary seat was to establish a principle that the Lebanese were interested in Ghanaian politics. It did not matter if he did not win the election. Gabby Mattouk is not a loser, and he insisted that if he were to run, the Lebanese community would have to support him with sufficient resources to enable him to win. The prospect of an open participation in politics was, understandably, unnerving for several Lebanese and the matter was dropped. At the 2001 CDD forum with which I started this article, some Ghanaians encouraged the Lebanese-Ghanaians to be proactive in politics, and not to wait for an invitation to be extended to them to become political actors. But considering the history of political antagonism towards the Lebanese, their reluctance to participate in politics is understandable. Here the 'politics of recognition', which Appiah argues is essential to identity, might help resolve this stand-off. Though Appiah advocates that the state stay out of identity formation in a multicultural society, he concedes that in specific situations the state could intervene to support or empower a marginalized group. He opines that the responses of people play a crucial role in shaping what we think of ourselves. Thus, Ghanaian insistence that the Lebanese-Ghanaians are not Ghanaian when it comes to politics compels this group to be politically quiescent. The state may play a role in the politics of recognition by, for example, sustaining identities held in political or social contempt within a society. For Appiah, a politics of recognition buffers a recognition of politics (Appiah 2005: 100-1). With our new understanding of the nature of the Lebanese diaspora in west Africa and Ghana, an awareness of how utilitarian familialism plays out in trading diasporas and has promoted endogamy among the Lebanese, and a new Ghanaian appreciation of transmigration and links between host societies and home, the Ghanaian state could meet the Lebanese community half-way through the politics of recognition.

\footnotetext{
${ }^{28}$ Interview with Adelaide Anno-Kumi, Deputy Director, Ministry of Interior, Accra, 8 February 2006.
} 


\section{CONCLUSION: COSMOPOLITAN PATRIOTS}

The amendment of the Ghanaian Constitution in 1996 to allow dual citizenship suggests that the Ghanaian government has come to terms with the reality that people can have dual nationalities and still be loyal to their place of origin and their place of abode. Dual citizenship excludes the holder from certain positions considered sensitive, such as an ambassadorship, the secretary to the cabinet, the inspectorgeneral of police, and the director of the immigration service. At present dual citizenship operates largely to the benefit of Ghanaians by birth, who would have been compelled to give up their Ghanaian citizenship because they had naturalized as citizens elsewhere. The current Immigration Act 573 of 2000 allows the right of abode for Ghanaians who have acquired citizenship in countries that do not allow dual citizenship, such as Germany, and for people of African descent. Spouses married to Ghanaians and who have stayed in Ghana for four years or more, and those who have run businesses in Ghana for ten years or more, can be granted indefinite residence under the same Act.

The response of Lebanese-Ghanaians to dual citizenship has been enthusiastic. Lebanon has long allowed dual citizenship and it was the Ghanaian restriction that made this unfeasible for Lebanese-Ghanaians. According to the current Chargé d'Affaires of the Lebanese Embassy in Ghana, Lebanese-Ghanaians who have acquired dual citizenship prefer to travel to Lebanon on their Ghanaian passports, even though this means paying a fee for a Lebanese visa. He opined that the LebaneseGhanaians show a strong attachment to their Ghanaian passports. He highlights how Ghanaian-Lebanese distinguish between place of origin and place of residence, family and social life, and have managed to combine these harmoniously. ${ }^{29}$ Appiah has advanced our understanding of cosmopolitanism and cosmopolitan patriots, showing that being a 'citizen of the world' (a cosmopolitan) does not conflict with improving the place you reside: 'A citizen of the world can make the world better by making some local place better, even though that place need not be the place of her literal or original citizenship' (Appiah 2005: 241). This endorses Mamdani's position that 'political communities are defined, in the final analysis, not by a common past but by a resolve to forge a common future under a single political roof, regardless of how different or similar their pasts may be' (Mamdani 2004: 17). And Mamdani offers common residence over common descent (indigeneity) as one way of forging a common political future.

If we remember that cosmopolitanism and nationalism, often portrayed as opposites, share a common assumption - affinity with an imagined community of strangers (within the nation and within the world) - the antithetical relationship is removed (Appiah 2005: 238). ${ }^{30}$ If we can relate to strangers within our imagined nation that

\footnotetext{
${ }^{29}$ Interview with Tony Eid, Lebanese Embassy, Accra, 6 February 2006.

30 The classic work on imagined communities remains Benedict Anderson (1983). For Anderson, nations are imagined as most of the residents do not see or know each other.
} 
we never see face-to-face, we can relate to political strangers within the same national space. Transnationalism seems to be dissolving the 'nation' component in 'nation state', and while states remain relevant and provide the structures and institutions that shape and direct the global flows that have excited globalization scholars, it has become increasingly difficult to maintain the fiction that a nation state holds people who share the same origins, language and culture. There is talk of how transmigration is leading to a deterritorialized nation state, 'in which the nation's people may live anywhere in the world and still not live outside the state' (Basch, Schiller and Blanc 1994: 269). The post-nation state would then be a 'state' delinked from 'nation'.

\section{REFERENCES}

Akyeampong, E. (2000) 'Africans in the diaspora: the diaspora and Africa', African Affairs 99 (395): 183-215.

(2001) 'African-Lebanese relations in west Africa: a historical perspective'. Paper presented at the Centre for the Advanced Study of the African Society Workshop on Racism, Racial Discrimination, Xenophobia and Related Intolerance, Durban (South Africa).

- (2006) 'Memories of place and belonging: identity, citizenship, and the Lebanese in Ghana', Ghana Studies (forthcoming).

Anderson, B. (1983) Imagined Communities: reflections on the origin and spread of nationalism. London: Verso.

Appiah, K. A. (2005) The Ethics of Identity. Princeton: Princeton University Press.

Basch, L., N. G. Schiller and C. S. Blanc (1994) Nations Unbound: transnational projects, postcolonial predicaments, and deterritorialized nation states. Amsterdam: Gordon and Breach.

Bauer, P. T. (1954) West African Trade: a study of competition, oligopoly and monopoly in a changing economy. Cambridge: Cambridge University Press.

Bierwirth, C. (1999) 'The Lebanese communities of Côte d'Ivoire', African Affairs 98 (390): 79-99.

Bigo, D. (1992) 'The Lebanese community in the Ivory Coast: a non-native network at the heart of power', in Albert Hourani and Nadim Shehadi (eds), The Lebanese in the World: a century of emigration. London: Centre for Lebanese Studies.

Boahen, A. A. (2000) Ghana: evolution and change in the nineteenth and twentieth centuries. Accra: Sankofa Educational Publishers.

Boumedouha, S. (1990) 'Adjustment to west African realities: the Lebanese in Senegal', Africa 60 (4): 538-49.

Braziel, J. E., and Anita Mannur (eds) (2003) Theorizing Diaspora. Malden: Blackwell Publishing Ltd.

Brydon, L. (1985) 'Ghanaian responses to the Nigerian expulsions of 1983', African Affairs 84 (337): 561-85.

Castles, S., and Alastair Davidson. (2000) Citizenship and Migration: globalization and the politics of belonging. New York: Routledge.

A common language and print media enable the simultaneous consumption of news that sustains the sense of a shared community. 
Cohen, R. (2003) Global Diasporas: an introduction. Seattle: University of Washington Press.

Cooper, F. (2001) 'What is the concept of globalization good for? An African historian's perspective', African Affairs 100: 189-213.

Falola, T. (1990) 'Lebanese traders in southwestern Nigeria, 1900-1960', African Affairs 89 (357): 523-53

(2001) Nationalism and African Intellectuals. Rochester: University of Rochester Press.

Fawaz, L. T. (1983) Merchants and Migrants in Nineteenth-Century Beirut. Cambridge: Harvard University Press.

Gates, C. L. (1998) The Merchant Republic of Lebanon: rise of an open economy. London: I. B. Tauris.

Gold Coast (1932) Appendices Containing Comparative Returns and General Statistics of the 1931 Census. Accra: Government Printer.

Hashimoto, H. (1992) 'Lebanese movement 1920-1939: towards a study', in Albert Hourani and Nadim Shehadi (eds), The Lebanese in the World: a century of emigration. London. Centre for Lebanese Studies.

Hourani, A. (1992) 'Introduction', in Albert Hourani and Nadim Shehadi (eds), The Lebanese in the World: a century of emigration. London: Centre for Lebanese Studies.

Humphrey, M. (1998) Islam, Multiculturalism and Transnationalism: from the Lebanese diaspora. London: I. B. Tauris Publishers.

Issawi, C. (1992) 'The historical background of Lebanese emigration, 1800-1914', in Albert Hourani and Nadim Shehadi (eds), The Lebanese in the World: a century of emigration. London: Centre for Lebanese Studies.

Leighton, N. O. (1979) 'The political economy of a stranger population: the Lebanese of Sierra Leone', in William A. Shack and Elliot P. Skinner (eds), Strangers in African Societies Berkeley: University of California Press.

Lessinger, J. (1992) 'Investing or going home? A transnational strategy among Indian immigrants in the United States', in Nina G. Schiller, Linda Basch, and Cristina Blanc-Szanton (eds), Towards a Transnational Perspective on Migration. New York: National Academy of Sciences.

Malkki, L. (2005) 'Genealogies of world order: forgotten cosmopolitical possibilities in the post-World War II era'. Cambridge: paper presented at Harvard University.

Mamdani, M. (1996) Citizen and Subject: contemporary Africa and the legacy of late colonialism. Princeton: Princeton University Press.

- (2004) 'Beyond settler and native as political identities: overcoming the political legacy of colonialism'. Cambridge: paper presented at Harvard University.

Mbembe, A. (2002) 'African modes of self-writing', Public Culture 14 (1): $239-73$.

Ong, A. (1999) Flexible Citizenship: the cultural logics of transnationality. Durham: Duke University Press.

Rado, E. (1986) 'Notes towards a political economy of Ghana today', African Affairs 85 (341): 563-72.

Ranger, T. (1983) 'The invention of tradition in colonial Africa', in Eric Hobsbawm and Terrence Ranger (eds), The Invention of Tradition. Cambridge: Cambridge University Press.

Republic of Ghana (1987) 1984 Population Census of Ghana: demographic and economic characteristics. Accra: Statistical Service.

Schiller, N. G., L. Basch and C. Blanc-Szanton (1992) 'Transnationalism: a new analytic framework for understanding migration,' in Schiller et al. 
(eds), Towards a Transnational Perspective on Migration. New York: National Academy of Sciences.

Twum-Baah, K. A., J. S. Nabila and A. F. Ayee (1995) Migration Research Study in Ghana, Vol. 2: international migration. Accra: Ghana Statistical Service. van der Laan, H. L. (1975) The Lebanese Traders in Sierra Leone. The Hague: Mouton Publishers.

- (1992) 'Migration, mobility and settlement of the Lebanese in west Africa', in Albert Hourani and Nadim Shehadi (eds), The Lebanese in the World: a century of emigration. London: Centre for Lebanese Studies.

\section{ABSTRACT}

As we approach the post-colonial half century, transnationalism has become a major reality in Africa and the wider world with the proliferation of immigrants, refugees and displaced persons. But transnationalism is not a new development, and diaspora and globalization - both historical processes - have long served as contexts for the remaking of identity, citizenship and polity. Today, concepts such as 'cosmopolitanism' and 'flexible citizenship' are in vogue in a globalized world, as transnationalism challenges statist concepts of political citizenship. In this article, using the case of Ghana, I revisit the historic presence of a Lebanese diaspora in west Africa from the 1860s, and the intellectual and political obstacles that have worked against their full incorporation as active political citizens. I seek to understand why the prospect of non-black citizenship was considered problematic in black Africa during the era of decolonization, interrogating the institutional legacies of colonial rule and pan-Africanist thought. The intellectual rigidity of pan-Africanism on race is contrasted with current notions of the constructedness of identity. I probe the ways in which the Lebanese in Ghana constructed their identities, and how these facilitated or obstructed assimilation. As African governments seek to tap into the resources of the new African communities in Europe and North America, the article suggests the timeliness of exploring alternative criteria to indigeneity when defining citizenship in black Africa.

\section{RÉSUMÉ}

Alors que nous approchons du demi-siècle post-colonial, le transnationalisme est devenu une réalité majeure en Afrique comme ailleurs avec la prolifération des immigrants, des réfugiés et des déplacés. Or, le transnationalisme n'est pas un élément nouveau et les processus historiques que sont la diaspora et la mondialisation servent depuis longtemps de contexte de remodelage de l'identité, de la citoyenneté et de l'organisation étatique. Aujourd'hui, des concepts comme le «cosmopolitisme» et la «citoyenneté flexible» sont en vogue dans un monde globalisé, alors que le transnationalisme remet en cause les concepts étatiques de citoyenneté politique. Dans cet article, l'auteur revisite, à travers le cas du Ghana, la présence historique d'une diaspora libanaise en Afrique de l'Ouest depuis les années 1860, et les obstacles intellectuels et politiques à leur pleine incorporation en tant que citoyens politiques actifs. Il cherche à comprendre pourquoi la perspective d'une citoyenneté non-noire était jugée problématique en Afrique noire pendant la période de la décolonisation, en interrogeant l'héritage institutionnel du régime colonial et de la pensée panafricaniste. L'article met en contraste la rigidité intellectuelle du panafricanisme sur les questions de race avec les notions courantes d'interprétation de l'identité. Il explore la manière dont les 
Libanais ont construit leurs identités au Ghana et comment celles-ci ont facilité ou gêné leur assimilation. À l'heure où les gouvernements africains cherchent à exploiter les ressources des nouvelles communautés africaines en Europe et en Amérique du Nord, l'article suggère qu'il est opportun d'explorer d'autres critères d'indigénéité pour définir la citoyenneté en Afrique noire. 